\title{
The Influence of Brand Image, Brand Trust, Product Quality, and Price on the Consumer's Buying Decision of MPV Cars
}

\author{
Amron Amron \\ Economic and Business Faculty, \\ Dian Nuswantoro University, Semarang, Indonesia
}

Doi: 10.19044/esj.2018.v14n13p228 URL:http://dx.doi.org/10.19044/esj.2018.v14n13p228

\begin{abstract}
This paper focuses on testing the model of consumer's buying decision of Multi-Purpose Vehicle (MPV) cars. The research model involved four independent variables of brand image, brand trust, product quality and price; and the dependent variable of buying decision. The study found that the four independent variables were proven to be capable of positively and significantly influencing consumer's decision in buying MPV cars. However, this study also found that, surprisingly, the variable of prices has the greatest effect compared with the other independent variables influencing consumer's buying decisions. This study suggested to managements of companies not to only focus their efforts on improving brand image and brand trust from the consumers' perspective, but to also strive to provide quality products at competitive prices.
\end{abstract}

Keywords: Brand Image, Brand Trust, Product Quality, Price, Buying Decision

\section{Introduction}

Recently, one of the fastest growing industries in Indonesia is the automotive industry. Its development is marked by the continued increase in the type and number of vehicles owned by people in the country. Today, car is no longer for the elite alone, but it has penetrated the middle and semimiddle classes. This fact is a major motivation used by car manufacturers to launch various kinds of brand new cars (Gaikindo, 2016).

Car brands in the automotive market in Indonesia are currently coming from Europe and Asia. Examples of these brands are Mitsubishi, KIA, Honda, Daihatsu, Suzuki, Ford, Proton, and Toyota. In 2015 and 2016, Toyota ranked first with the sales of 321,818 units, and then it increased its sales in 2016 to 381,570 units (Gaikindo, 2016). The second highest position was occupied by 
Daihatsu at 167,808 units in 2015 which later increased to 189,683 units in 2016. The third rank was Mitsubishi Motors with the sales of 76,326 units in 2015 and 66,443 units in 2016 (Gaikindo, 2016). Based on the total sales, more than $50 \%$ of the cars belong to the kind of Multi-Purpose Vehicle (MPV) that has a passenger capacity of more than 5 people (Gaikindo, 2016). MPV car is intended for transporting people, particularly those with many family members. Therefore, the car features of MPV were designed to transport passengers comfortably.

Recently, MPV cars such as Toyota Avanza, Daihatsu Xenia, and Toyota Inova are the types of MPV cars sold in Indonesia today. In 2016, Toyota Avanza was ranked first by the Top Brand Index (TBI) with the TBI level of $43.6 \%$. Moreover, their competitors such as Daihatsu Xenia and Kijang Innova, with the TBIs of 14.1 percent and 11.1 percent respectively, had sales of over 300,000 units (Topbrand, 2016). However, an increasing number of sales mentioned above were followed by increasingly competitive rivalry. For example, the entry of major competitors, such as Suzuki MPV, Mobilio Honda, and Suzuki Ertiga offering the type of MPV cars in the period from 2015 to 2016 cannot be underestimated. The estimated future production of the MPV cars of Toyota and Daihatsu will be shifted by the brands of Honda and Suzuki MPV (Gaikindo, 2016). Therefore, MPV car manufacturers need to make efforts to anticipate the competition including consumer's interest to remain loyal in buying MPV cars. Based on the above description, it is necessary to examine the factors that influence consumers to decide to buy the product of MPV cars.

The purpose of this study was to test the model of the buying decision of MPV cars by placing four independent variables of brand image, brand trust, product quality, and price by taking the objects of the MPV car owners in Bandung city, Indonesia. This research is useful for the managements of companies to formulate their promotional strategies in order to increase the number of MPV car buyers. In addition, it is useful for marketers to explore consumers to be always loyal to buy MPV cars. 
Figure 1. Model of Buying Decision

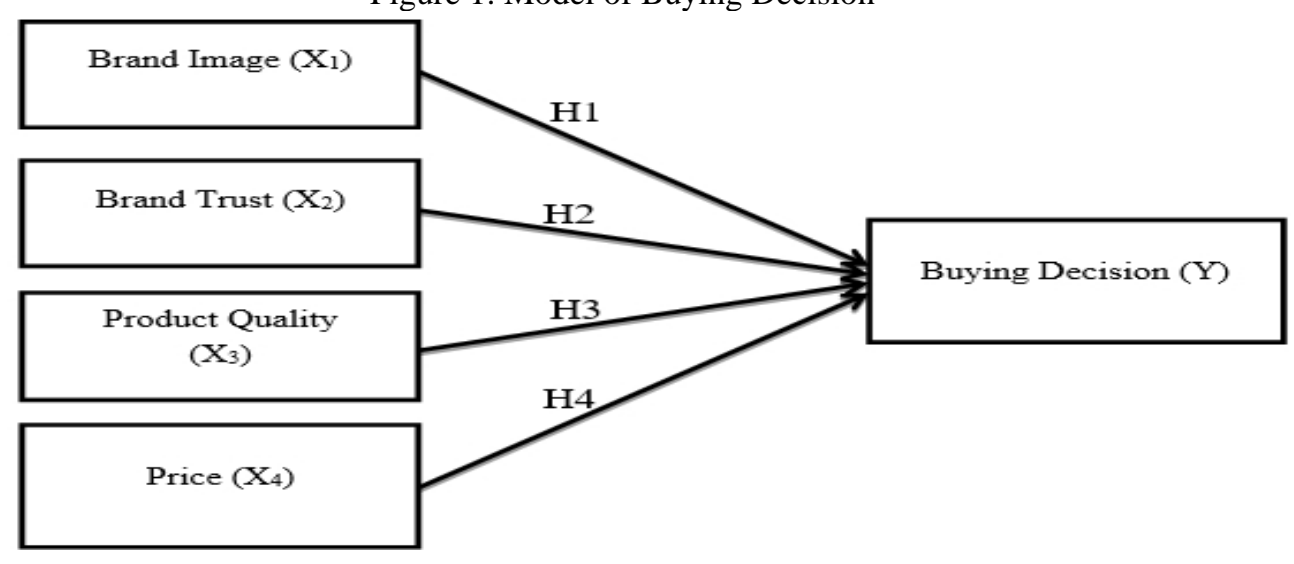

\section{Theoretical Background Buying Decision}

Buying decision is a selection of two or more options to carry out purchases (Dowling, 1986; Chang \& Wang, 2011). Buying decision is particularly important when there are many options with the same function for the goods and services (Monroe, 2002; Amron \& Usman, 2016). The buying decision made by consumers is based on various motives and specific impulses. The stronger the consumer's impulse and motives, the stronger the decision to buy a particular product (Chang \& Wang, 2011; Bai \& Qin, 2016).

Companies must be able to capture consumer's impulse and motive them to make purchases (Diallo et al., 2013; Monroe, 2002). They are also required to be able to make a product that can meet the expectations and motives of consumers to buy the goods. Manufacturers should be able to position the product to be meaningful in consumer's preferences in deciding to purchase the goods (Dowling, 1986). It is not easy for manufacturers to create the products which are always in consumer's demand. However, in principle, it might be possible to do so if producers are able to capture consumer behavior in determining their choices (Monroe, 2002).

Consumer behavior includes the behaviors of individuals or groups of consumers in assessing an item to be bought (Pavlou et al., 2007). Consumer behavior is influenced by various factors, such as educational level, age, income level, taste and so forth. According to Sasmita and Suki (2015), buying decision is influenced by brand image. Meanwhile, according to Alwi et al. (2016), buying decision is influenced by brand trust. Furthermore, Beneke et al. (2013) found that buying decision is influenced by product quality and price.

\section{Brand Image and Buying Decision}

Image is a form of belief held by consumers for the goods to be bought (Lau \& Phau, 2007). Brand Image is the perception and beliefs held by 
customers about a specific product (Lau \& Phau, 2007; Rubio et al., 2014). It is embedded in the memory of consumers and will be reflected in consumer's buying behavior (Diallo et al., 2013).

Diallo et al. (2013) puts brand image as consumer understanding based on the type of a particular brand. When it is increasingly embedded in the memory of consumers, a brand will become more close to the consumer's choice. Therefore, a good brand image should be introduced to consumers continuously so as to form a memory attached to them (Lau \& Phau, 2007). The emerging brand impression in consumer's memory increases along with the increasing number of consumers to experience the brand (Rubio et al., 2014). Furthermore, when brand association is interconnected strongly, the brand image that is formed will also become more powerful (Lau \& Phau, 2007).

Various studies attributing the strong relationship between brand image and buying decision had been conducted by researchers involving various aspects. For example, the research of Sasmita and Suki (2015) examined the strength of the relationship between the brand image on the buying decision of 200 respondents in buying branded goods in Malaysia. Furthermore, the study underlined that there is a positive and significant relationship between brand image and consumer's buying decisions. The research conducted by Watson et al. (2015) investigated the influence of brand image on the buying decision of branded apparel products in Germany. The results found that brand image is able to influence buying decision in a positive direction. Concerning the matters above, the researcher formulated hypotheses that brand image has a positive effect on the consumer's buying decision of MPV cars.

H1: Brand image has a positive and significant effect on consumer's buying decision.

\section{Brand Trust and Buying Decision}

Brand trust is the view of consumers towards a particular brand (Pavlou et al., 2007; Morgan \& Hunt, 1994). Consumer outlook is based on the information and experiences that lead to a product performance. The trust given to a brand refers to consumer's expectations that a product is able to fulfill its promise made to consumers (Han \& Sung, 2008). Product performance is very close to the trust in the brand. Trust is built by the hope that the other party will act in accordance with the needs and desires of consumers (Han \& Sung, 2008).

Various studies establishing the association between brand trust and buying decision had been conducted by previous researchers. For example, Alwi et al. (2016) examined the effect of buying decision on air conditioning products in Malaysia by placing brand trust as the independent variable. The result shows that brand trust is able to influence consumer's buying decision 
in a positive and significant direction. In addition, the research of Chinomona (2016) also used the variable of brand trust to test the product's buying decision in South Africa. The research results showed that brand trust influences buying decision in a positive direction. Therefore, we proposed that there is a positive association between brand image developed well with MPV car buying decision.

$\mathrm{H} 2$ : There is a positive and significant relationship between brand image with consumer's buying decision of MPV cars.

\section{Product Quality and Buying Decision}

Product quality is the product ability to satisfy the needs or desires of consumers (Nilsson et al., 2001). Marketers who do not pay attention to the quality of the products or services offered would lose as consumers become disloyal (Amron, 2017). As a result, the sales of products or services will tend to decline (Amron \& Mahmud, 2017). When marketers pay attention to quality, consumers will be happy to decide to buy a product or service. According to Sebastianelli and Tamimi (2002), product quality is the totality of the features and characteristics of the products or services that depends on their ability to satisfy stated or implied needs.

Various studies associating product quality with buying decision had been made by researchers to associate with various aspects. For example, Beneke et al. (2013) examined the effect of product quality on buying decision of other household goods. The results showed that product quality has positive effect on buying decisions. Then, the research conducted by Kianpour et al. (2014) found that product quality has positive significant effect on the postgraduate students of Universiti Teknologi Malaysia. Therefore, the writer formulated the positive and significant association between product quality with buying decision as follows:

H3: Product quality is significantly and positively associated with the buying decision of MPV cars.

\section{Price and Buying Decision}

Price is an element that generates revenue for producers of goods (Monroe, 2002; Kenning et al., 2011). According to Eberhardt et al. (2009), price is the amount of money charged for the product or service purchased by customers. It is a flexible marketing element which is easily changed according to time and place. Price is not only in figures of product label, but it can take many forms in performing many functions (Kenning et al., 2011). Rent, wages, rates, storage costs, and interest are the prices to be paid to obtain goods (Eberhardt et al., 2009).

Various studies associating prices and buying decision had been conducted by previous researchers. For example, Rodiger et al. (2016) 
examined the effect of price on supermarket consumer's buying decision in Germany. The result shows that competitive price has a significant and positive effect on buying decisions. Kuo and Nakhata (2016) also insisted in their research that competitive price has positive effect on buying decisions. Concerning the matters, the researcher concluded that competitive price has a positive effect on consumer's buying decisions (see also Figure 1).

H4: Price has positive and significant effect on consumers in deciding to buy MPV cars.

\section{Research Method}

This study used questionnaires to obtain primary data. The questionnaires were distributed to 115 respondents who owned MPV cars and are residing in Bandung, Indonesia. The questionnaires included two main sections: the section that asks the respondent's identity, such as; age, sex and occupation, and the second section which contains an instrument that asked of the respondent's perception to the variables studied including the independent variables of brand image, brand trust, product quality, and price. The incoming data were tabulated, and then they were processed and interpreted. This study used the data processing instrument of SPSS.

\section{Results and Discussion}

\section{Respondent Description}

A total of 115 questionnaires were distributed. The results indicated that only 109 out of the distributed questionnaires were returned. Out of it, 100 questionnaires were declared good and feasible to follow up. By the age of the respondents, 10 percent was aged between 21 and 29 years, 51 percent between 30 to 39 years old, 32 percent between 40 and 49 years old, and the remaining 7 percent was over the age of 50 years. By sex, 78 percent of them was male, and the other 22 percent was female. By the respondents' occupation, it shows that 61 percent of them worked in private companies, 17 percent as civil servants, and the remaining 22 percent of them had their own businesses. All respondents replied that the MPV cars were their own cars, and the respondents were domiciled in Bandung, Indonesia.

\section{Validity and Reliability Tests}

The validity test of this research shows the smallest $r$ value of 0.621 and the largest $r$ count of 0.941 . The value of $r$ table of this study obtained the value of 0.196 (see Table 1). Referring to the provisions of the value of $r$ count $>\mathrm{r}$ table, the research questionnaires were declared valid. Therefore, they were considered to be able to express something measured by the research questionnaires. 
The reliability test shows that the smallest cronbach alpha value is 0.668 , while the highest value is 0.859 . Referring to the stipulation that the value of cronbach alpha should be higher than 0.60 , it can be concluded that all concepts of the measurement of each variable of the questionnaire are reliable. Therefore, the items in each of the variable concepts were declared feasible and could be used as a measuring instrument (see Table 2).

\section{Normality, Heteroscedasticity, and Multicolinearity Tests}

The normality test of this research used P-Plot graph. Based on the test, it was found that the points on the P-Plot graph coincide and follow the direction of the diagonal line. Then, it can be concluded that the data is normally distributed. In addition to the normality test, this study also conducted a heteroscedasticity test. The test was conducted using the Scatterplot chart. The result shows that the points on the graph do not form a clear pattern, and the points spread higher and lower than 0 on the Y-axis. It is concluded that there is no heteroscedasticity.

The multicollinearity test in this study was indicated by the tolerance values and variance infiation factor (VIF) values. The smallest tolerance value in this study was 0.442 and the largest one was 0.492 . With reference to the provision of tolerance value $>0.10$, it can be concluded that the tolerance values of this study meets the requirements. Similarly, the value of the variance infiation factor (VIF) fulfilled the VIF requirement $<10$. Since the smallest VIF value of this study is 2.078 and the largest one is 2.269 , it can be concluded that the variables in the regression model of this study have no multicollinearity.

\section{F-test dan t-test}

The F-test in this study resulted in the F-count of 60.468 , with a significance level of 0.000 . With reference to the provisions that sig value is lower than $0.05(\alpha=0.05)$, the F-test of this research meets the requirement. It can be concluded that all of the independent variables in this study collectively have significant effect on the variable of buying decision.

The t-test results in this study show the lowest value of 2.250 with sig. 0.028 and the highest value of 5.145 with sig. 0.000 . With reference to the provisions of sig. $<0.05$, it can be concluded that all the hypothesis were accepted.

\section{The Results of Multiple Regression}

The Multiple Regression results of this study can be written in the multiple regression equation of $\mathrm{Y}=0.119+0.229 \mathrm{X} 1+0.188 \mathrm{X} 2+0.181 \mathrm{X} 3$ $+0.289 \mathrm{X} 4$. The sig. results of each variable were brand image sig. of 0.008 , brand trust sig. of 0.023 , product quality sig. of 0.028 , and the price sig. of 
0.000 . The regression equation of this study explains the constant $(\alpha)$ of 0.119 , meaning that if brand image, brand trust, products quality, and price are zero, the buying decision is positive.

The regression coefficient, which shows the positive values $(0.229$ $\left(b_{1}\right) ; 0.188\left(b_{2}\right) ; 0.181\left(b_{3}\right)$, and $\left.0.289\left(b_{4}\right)\right)$, show that every increase in the independent variable will increase the dependent variable in a positive direction. As an example, the regression coefficients of the independent variable of brand image $\left(b_{1}\right)$ is positive at 0.229 . Therefore, it can be interpreted that every improvement in brand image will increase the buying decision with a significance level of 0.008 .

Table 1. Validity Test

\begin{tabular}{|c|c|c|c|c|}
\hline Variable & Indicator & $\begin{array}{c}\text { Correlation } \\
\text { Coefficient (r) }\end{array}$ & r-table & Remark \\
\hline \multirow{3}{*}{$\mathrm{X} 1$} & $\mathrm{X} 1.1$ & 0.733 & \multirow{3}{*}{0.196} & Valid \\
\hline & $\mathrm{X} 1.2$ & 0.787 & & Valid \\
\hline & $\mathrm{X} 1.3$ & 0.865 & & Valid \\
\hline \multirow{4}{*}{$\mathrm{X} 2$} & $\mathrm{X} 2.1$ & 0.877 & \multirow{4}{*}{0.196} & Valid \\
\hline & $\mathrm{X} 2.2$ & 0.941 & & Valid \\
\hline & $\mathrm{X} 2.3$ & 0.821 & & Valid \\
\hline & $\mathrm{X} 2.4$ & 0.684 & & Valid \\
\hline \multirow{4}{*}{ X3 } & $\mathrm{X} 3.1$ & 0.804 & \multirow{4}{*}{0.196} & Valid \\
\hline & $X 3.2$ & 0.801 & & Valid \\
\hline & $X 3.3$ & 0.712 & & Valid \\
\hline & X3.4 & 0.621 & & Valid \\
\hline \multirow{4}{*}{$\mathrm{X} 4$} & $\mathrm{X} 4.1$ & 0,763 & \multirow{4}{*}{0.196} & Valid \\
\hline & $\mathrm{X} 4.2$ & 0.766 & & Valid \\
\hline & $\mathrm{X} 4.3$ & 0.814 & & Valid \\
\hline & $\mathrm{X} 4.4$ & 0.793 & & Valid \\
\hline \multirow{4}{*}{ Y } & Y.1 & 0.752 & \multirow{4}{*}{0.196} & Valid \\
\hline & Y.2 & 0.751 & & Valid \\
\hline & Y.3 & 0.680 & & Valid \\
\hline & Y.4 & 0.784 & & Valid \\
\hline
\end{tabular}

Source : Processed Data Processing

Table 2. Reliability Test Results

\begin{tabular}{|c|c|c|c|}
\hline \multirow[t]{2}{*}{ Variable } & \multicolumn{2}{|c|}{ Cronbach Alpha } & \multirow{2}{*}{ Remark } \\
\hline & Criteria & Results & \\
\hline $\mathrm{X} 1$ & \multirow{5}{*}{$>0.60$} & 0.668 & Reliable \\
\hline $\mathrm{X} 2$ & & 0.859 & Reliable \\
\hline $\mathrm{X} 3$ & & 0.788 & Reliable \\
\hline $\mathrm{X} 4$ & & 0.715 & Reliable \\
\hline $\mathrm{Y}$ & & 0.732 & Reliable \\
\hline
\end{tabular}

Source: Processed Primary Data 


\section{Discussion}

This study was aimed to test the model of the consumer's buying decision of MPV cars in Bandung, Indonesia. The buying decision model in this study employed brand image, brand trust, product quality, and price as the independent variable, while the buying decision in this study served as the dependent variable. This study found that the four independent variables were proven to be capable of influencing consumer decision in buying the product of MPV cars in a positive and significant direction. However, surprisingly, the variable of price has the greatest effect compared with the other independent variables of 0.289 with a significance level of 0.000 .

In terms of price, the results of this study indicate that a very competitive price influences consumer's decision (Kenning et al., 2011). The positive and significant impact of this study can be interpreted: if price matches the quality, it will improve buying decisions. This study was in line with the research of Kuo and Nakhata (2016) and Rodiger et al. (2016), but it was different from the two previous studies because, in the opinion of respondents, it placed price indicator that corresponded to the types of products which were considered to be most important to look at the price. The respondents argued that the definition of competitive price shows that the price must correspond to the features that the car has (Monroe, 2002; Eberhardt et al., 2009). The facts that describe the car's features will be the consumer's consideration in assessing the price. This study suggests to marketers to sell products in accordance with the facts in the field. This is because the cheap price, according to the consumers but not in accordance with the features offered, is not in the category of competitive prices.

The second and third findings were that the brand image and brand trust were able to influence consumer decision in determining the buying of MPV cars. Although both were significantly able to positively influence purchasing decisions, there was a striking difference between the two because the brand image had a greater effect than the brand trust. Besides, the level of significance of brand image was better than the brand trust. Increasingly, the automotive companies were able to build brand image and brand trust properly; so they had a direct impact on consumer decision to buy (Han \& Sung, 2008; Pavlou et al., 2007). These results are consistent with the studies of Sasmita and Suki (2015), Watson et al. (2015), Alwi et al. (2016), and Watson et al. (2015). This study suggests to the company managements to always keep the image and consumer confidence in order to create a strong brand and to firmly entrenched them in the consumer's minds (Rubio et al., 2014; Lau \& Phau, 2007). The way was by providing the information centers and after-sales service representative to build the image that MPV car is a family car which is very comfortable and has a satisfactory service. 
The fourth findings of this study show that product quality is able to influence consumer decision in a positive direction. The maintained quality presented to consumers with a high quality is able to increase buying decision. However, this study is in line with the studies of Beneke et al. (2013) and Kianpour et al. (2014). The study also suggests to the company managements to provide special features in addition to the facility of efficient fuel use. The respondents argued that consumers choose MPV cars not only because it is economical based on fuel consumption, but based on the fact that it also has features that provide convenience and that are unique in nature. Also, company managements can make the shape of the seats such that it can be tilted automatically to improve passenger's comfort.

\section{Conclusion and Recomendation}

This study was aimed to test the model of consumer's buying decision comprehensively by taking the object of MPV car of consumers with the research site in Bandung, Indonesia. The study involved four independent variables of brand image, brand trust, product quality, and price, and buying decision was the dependent variable.

Although the results of this study showed that the four independent variables were able to influence consumer's decision, but surprisingly the variable of price has a great effect and better significance level compared with the other variables in influencing consumer's buying decision of MPV cars.

This study suggests to company managements to consider product features as well as comfort in the provision of facilities and infrastructure because the two components are considered by consumers as the most important factors in deciding to choose MPV cars beyond the fact that the fuel consumption of the car is economical. The study also suggests that marketers should build brand image and brand trust by always giving a pleasant explanation about the quality of the products and competitive prices in order to create a strong perception that MPV car is a comfortable family car.

\section{References}

1. Alwi, S.F.S, Nguyen, B., Melewar, T.C., Loh, Y.H. \& Liu, M. (2016). "Explicating industrial brand equity: Integrating brand trust, brand performance and industrial brand image", Industrial Management \& Data Systems, Vol. 116 No.5, pp.858-882.

2. Amron, A. (2017). "Marketing Challenge of Import Insurance Product in Indonesia", Advance Science Letters, Vol. 3 No. 8, 7243-7245.

3. Amron, A. \& Mahmud, M. (2017). "Developing Marketing Strategy in Property Insurance Business", International Business Management, Vol.11 No.1, pp.177-182. 
4. Amron, A \& Usman, U. (2016). "Customer Satisfaction in the Marketing of Inland Transit Insurance Service”, International Journal of Applied Business and Ecomonic Research, Vol. 14 No.12, pp. 83118321.

5. Bai, F. \& Qin, Y. (2016). The Implementation of Relationship Marketing and CRM : How to Become a Customer-Focused Organization, Journal of Business \& Economic Policy, Vol. 3 No. 2, pp. 112-124.

6. Beneke, J., Flynn, R., Greig T. \& Mukaiwa, M. (2013). "The influence of perceived product quality, relative price and risk on customer value and willingness to buy: a study of private label merchandise", Journal of Product \& Brand Management, Vol. 22 No. 3, pp. $218-228$.

7. Chang, H.H. \& Wang, H.W. (2011). "The moderating effect of customer perceived value on online shopping behaviour", Online Information Review, Vol. 35 No. 3, pp. 333-359.

8.Chinomona, R. (2016). "Brand communication, brand image and brand trust as antecedents of brand loyalty in Gauteng Province of South Africa", African Journal of Economic and Management Studies, Vol. 7 No.1, pp.124-139.

9. Diallo, F.M., Chandon, J.L., Cliquet, G. \& Philippe, J. (2013). "Factors influencing consumer behaviour towards store brands: evidence from the French market", International Journal of Retail \& Distribution Management, Vol. 41 No. 6, pp. 422-441.

10. Dowling, G.R. (1986). "Perceived risk: the concept and its measurement", Psychology \& Marketing, Vol. 3 No. 3, pp. 193-210.

11. Eberhardt, T., Kenning, P. \& Schneider, H. (2009). "On the validity of price knowledge measurements via self-assessment scales: Two studies in retailing", Journal of Targeting, Measurement and Analysis for Marketing, Vol. 17 No. 2, pp. 93-103.

12. Gaikindo (2016). Indonesian Automobile Industry Data. Availabel at : https://www.gaikindo.or.id/indonesian-automobile-industry-data/ (Accesed Date: 30 December 2016).

13. Han, S.L. \& Sung, H.S.(2008). "Industrial brand value and relationship performance in business markets - ageneral structural equation model", Industrial Marketing Management, Vol. 37 No. 7, pp. 807-818.

14. Kenning, P., Hartleb, V. \& Schneider, H. (2011). "An empirical multimethod investigation of price knowledge in food retailing", International Journal of Retail \& Distribution Management, Vol. 39 No. 5, pp. 363-382.

15. Kianpour, K., Jusoh, A. \& Asghari, M. (2014). "Environmentally friendly as a new dimension of product quality", International Journal of Quality \& Reliability Management, Vol. 31 No. 5, pp. 547 - 565. 
16. Kuo, H.C. \& Nakhata, C. (2016). "Price promotions and products with low consumer ratings", Journal of Consumer Marketing, Vol. 33 No. 7, pp. 517-527.

17. Lau, K.C. \& Phau, I. (2007). "Extending symbolic brands using their personality: examining antecedents and implications towards brand image fit and brand dilution", Psychology and Marketing, Vol. 24 No. 5, pp. 421-444.

18. Monroe, K.B. (2002). Pricing: Making Profitable Decisions, $3^{\text {rd }}$ ed., McGraw-Hill, New York, NY.

19. Morgan, R.M. \& Hunt, S.D. (1994). "The commitment-trust theory of relationship marketing", Journal of Marketing, Vol. 58 No. 3, pp. 2038.

20. Nilsson, L., Johnson, M.D. \& Gustafsson, A. (2001). "The impact of quality practices on customer satisfaction and business results: product versus service organizations", Journal of Quality Management, Vol. 6 No. 1, pp. 5-27.

21. Pavlou, P. A., Liang, H. \& Xue, Y. (2007). "Understanding and mitigating uncertainty in online exchange relationships: A principalagent perspective", MIS Quarterly, Vol. 31 No. 1, pp. 105-136.

22. Rodiger, M., Plabmann, S. \& Hamm U. (2016). "Organic consumers' price knowledge, willingness-to-pay and purchase decision", British Food Journal, Vol. 118 No. 11, pp. 2732-2743.

23. Rubio, N., Oubiña, J. \& Villaseñor, N. (2014). "Brand awarenessbrand quality inference and consumer's riskperception in store brands of food products", Food Quality and Preference, Vol. 32 No. 2014, pp. 289-298.

24. Sasmita, J. \& Suki, N.M. (2015). "Young consumers' insights on brand equity", International Journal of Retail \& Distribution Management, Vol. 43 No. 3, pp. $276-292$.

25. Sebastianelli, R. \& Tamimi, N. (2002). "How product quality dimensions relate to defining quality", International Journal of Quality and Reliability Management, Vol. 19 No. 4, pp. 442-453.

26. Topbrand (2016). Indonesian Top Brand Award. Availabe at : http://www.topbrand-award.com/top-brand-survey/surveyresult/top_brand_index_2016_fase_1 (Accessed Date: 30 December 2016).

27. Watson, A., Lecki, N.K. \& Lebcir, M. (2015). "Does size matter? An exploration of the role of body size on brand image perceptions", Journal of Product \& Brand Management, Vol. 24 No. 3, pp. $252-$ 262. 